\title{
Antibodies to histones in systemic lupus erythematosus: prevalence, specificity, and relationship to clinical and laboratory features
}

\author{
Michael G Cohen, K Michael Pollard, John Webb
}

\begin{abstract}
Antibodies to histones (AHA) are commonly found in patients with systemic lupus erythematosus (SLE). However, the full profile of AHA and their clinical associations remains unclear. A total of 111 patients with SLE were studied, including 13 patients in whom multiple serum samples were available over several years. IgM, IgG, and IgA antibodies to total core histones, histone complexes, and individual histones were determined by highly sensitive enzyme linked immunosorbent assays (ELISAs). Antibodies to histones were detected in $74 \%$ of serum samples, though only at low levels in half of these. Antibodies to each of the individual histones (H1, H2A, H2B, H3, H4) occurred with similar frequencies except for IgG and IgA antibodies to H4, which were uncommon. In contrast, antibodies to the histone complexes H2AH2B and H3-H4 were detected in only two serum samples and thus do not appear to be a feature of SLE. All three major isotypes of AHA were common and usually occurred with similar frequencies to one another for the various histone specificities.

There were few clinical or laboratory associations with AHA; the strongest was between IgG antibodies to total core histones and antibodies to native DNA. Similarly, there was no association between the presence of AHA and disease activity. However, for the patients as a group and in one patient alone, periods of SLE disease activity were associated with higher levels of AHA. Although the profile of antibodies to individual histones varied with time, no profile was identified that corresponded with any specific disease manifestations. It is concluded from this study that although AHA are common in patients with SLE, their clinical value in this syndrome must, at present, be considered limited.
\end{abstract}

Sydney University

Department of

Rheumatology,

Sutton Rheumatism

Research Laboratories,

Royal North Shore

Hospital, St Leonards,

New South Wales 2065,

Australia

M G Cohen

K M Pollard

J Webb

Correspondence to:

Dr M G Cohen,

Department of Rheumatology,

Princess Alexandra Hospital,

Wrincess Alexandra Hospitiangabba, Brisbane

Queensland 4102, Australia.

Accepted for publication

12 February 1991

allowed their nature to be defined in greate detail than most other autoantibodies. Nonetheless, many reports have conflicting findings: the prevalence of AHA in patients with SLE has been variously reported to be as low as $21 \%^{3}$ or up to $81 \% .^{45}$ Some workers have observed associations between AHA and indices of disease activity ${ }^{6-9}$ whereas others have failed to show histone components has also differed from study to study. ${ }^{3} 5610 \quad 13-20$

In this work, we determined all the major isotypes of AHA (including antibodies to individual histones and histone complexes) in a large cohort of patients with SLE in both cross sectional and longitudinal studies. This has allowed the definition of the prevalence and clinical associations of AHA in our patients with SLE as well as addressing some of the factors that may have given rise to the disparities between earlier reports.

\section{Patients and methods}

PATIENTS AND SERUM SAMPLES

One hundred and eleven patients with SLE with serum samples stored at the department of rheumatology, Royal North Shore Hospital from 1970 to 1986 formed the basis of this study. All patients fulfilled the American Rheumatism Association revised criteria for SLE. ${ }^{21}$ All serum samples had been stored in aliquots at $-20^{\circ} \mathrm{C}$.

Patients charts were reviewed for clinical and laboratory findings including mucocutaneous lesions, arthritis, serositis, renal involvement, neurological lesions, haematological tests, antinuclear antibodies, rheumatoid factor, antibodies to native DNA, complement concentrations, and antibodies to extractable nuclear antigens.

In 13 patients, 190 sequential serum samples (median 15 per patient, range 5-28) obtained over a median period of 83 months (range 26-196 months) were available. Levels of antibodies to native DNA had been determined in all samples. The charts were reviewed to assess the disease activity by the lupus activity criteria count $^{22}$ at the times at which the serum samples were obtained. The lupus activity criteria count was chosen because it could be applied to retrospective data to categorise a patient as having either active or inactive SLE, although the degrees of activity could not be differentiated. In nine of the patients, sufficient information was available to determine the disease activity at the time the serum samples were obtained, except for four of 21 serum samples from one patient alone. this. ${ }^{10-12}$ The specificity of AHA for individual

\section{ASSAYS}

The routine estimation of rheumatoid factor titre was obtained with a commercial sensitised sheep cell agglutination technique (Rheumaton, Denver Laboratories). Antinuclear antibodies were detected using rat liver substrate as pre- 
viously described. ${ }^{23}$ Antibodies to native DNA were measured as the percentage binding in the Farr assay (normal value $<20 \%$ ). ${ }^{24}$ Antibodies to extractable nuclear antigens (SS-A/Ro, SSB/La, RNP, Sm) were detected by counterimmunoelectrophoresis or immunodiffusion in agarose gel with rabbit thymus extract (PelFreeze Biologicals) or guinea pig kidney extract. ${ }^{23}$ Routine complement C3 and C4 levels were measured by radial immunodiffusion. Complement levels in the serum samples used for the determination of AHA in the cross sectional study were measured again by rate nephelometry using a Beckman ICS nephelometer.

Antibodies to histone were measured by an enzyme linked immunosorbent assay (ELISA) as described previously. ${ }^{25}{ }^{26}$ Briefly, a preparation that was found to contain core histones ( $\mathrm{H} 2 \mathrm{~A}, \mathrm{H} 2 \mathrm{~B}, \mathrm{H} 3, \mathrm{H} 4)$ and a preparation containing $\mathrm{Hl}$ were obtained from Sigma Chemical. Individual histones were purified by the method of Bohm et al. ${ }^{27}$ Histone complexes were prepared as previously described. ${ }^{25} 28$ ELISA plates were coated with histones diluted in phosphate buffered saline (PBS), $\mathrm{pH} \mathrm{7.3}$ and then coated with PBS containing Tween 20 (PBST). Samples were diluted in PBST and bound antibody detected with enzyme conjugated antibodies to human IgM, IgG, or IgA (Silenus). Enzyme substrate was added and the colour change monitored with an automated spectrophotometer. Preliminary experiments determined that none of 30 AHA positive serum samples bound to PBST coated plates in the absence of antigen.

All serum samples were tested for antibodies to total core histones (AcHA) and H1. The upper limit of the normal level in all assays was defined as the mean plus three standard deviations of the absorbance of six serum samples from healthy blood donors, which were representative of 80 serum samples used to determine the normal range. These six serum samples and the one positive control were run in all assays. Units for AcHA were determined by ascribing unit values to the positive control serum sample (100 $\mathrm{U}$ for all isotypes) and to the upper limit of the normal level (12, 30, and 30 for IgG, IgM and $\operatorname{IgA}$, respectively). Only serum samples

Table 1 Occurrence of the American Rheumatism Association (ARA) 1982 revised criteria for the classification of systemic lupus erythematosus in various patient groups

\begin{tabular}{lcccc}
\hline Criterion & \multicolumn{3}{l}{ Prevalence (\%) } & \\
\cline { 2 - 5 } & This series & $\begin{array}{l}\text { fapan } \\
(29)^{*}\end{array}$ & $\begin{array}{l}\text { Singapore } \\
(4)^{*}\end{array}$ & $\begin{array}{l}\text { ARA } \\
(21)^{*}\end{array}$ \\
\hline Malar rash & 79 & 77 & 58 & 57 \\
Discoid lupus & 23 & 27 & 11 & 18 \\
Photosensitivity & 72 & 45 & 16 & 43 \\
Mouth ulceration & 38 & 25 & 19 & 27 \\
Arthritis & 95 & 80 & 67 & 86 \\
Pleuropericarditis & 51 & $>18 \dagger$ & $>7$ & 56 \\
Renal disease & $63 \ddagger$ & $>54$ & $>41$ & 51 \\
Central nervous system disease & $(46) \ddagger$ & $>14$ & $>22$ & 21 \\
Haematological & 94 & $>70$ & $>56$ & 59 \\
Immunological & 95 & $>90$ & $>46$ & 85 \\
Antinuclear antibodies & 100 & 99 & 97 & 99 \\
\hline
\end{tabular}

${ }^{*}$ Reference from which data were obtained.

tExact figures could not be stated where the authors have separated individual criteria into their component parts (e.g. stated figures for pleurisy and pericarditis)

$\ddagger$ Renal disease includes patients with biopsy evidence of lupus nephritis. Central nervous system involvement includes all abnormalities (e.g. seizures, psychosis, coma, organic brain syndrome) considered by the doctor to be secondary to SLE and for which no other cause subsequently became evident. with AcHA levels greater than twice the normal level were further tested for antibodies to individual core histones or histone complexes. Antibodies to histone complexes were stated to be present if the absorbance of the test serum sample was greater than twice the normal level and there was no increased binding to either of the component histones.

\section{STATISTICAL METHODS}

Possible associations between the antibodies and the characteristics of the disease for future prospective studies, were sought using the Pearson $\chi^{2}$ test. The Spearman rank correlation was used to compare antibody levels. The relationships between each of the AHA, antibodies to native DNA, the erythrocyte sedimentation rate (Westergren) and the lupus activity criteria count in the serially studied patients were assessed for the whole group using logistic regression. In individual patients, the Mann-Whitney test was used.

\section{Results}

CLINICAL AND LABORATORY CHARACTERISTICS The patient sample consisted of 105 women and six men with a median age of 38 years (range 15-70 years). The median duration of disease at the time the serum samples were collected was eight years (range $0-45$ years). Table 1 compares the prevalence of each American Rheumatism Association criterion in these 111 patients with those from other studies. ${ }^{4} 2129$

The prevalences of other features recorded in these patients were: Raynaud's phenomenon (68\%), vasculitis (26\%), antibodies to extractable nuclear antigen (52\%), decreased complement C3 (41\%) and C4 (74\%), and rheumatoid factor $(18 \%)$.

In the same serum samples used for the estimation of AHA, raised levels of antibodies to native DNA were observed in $32 \%$, decreased complement $\mathrm{C} 3$ in $19 \%$, and $\mathrm{C} 4$ in $15 \%$ of patients.

\section{ANTIBODIES TO HISTONES}

Increased levels of AcHA or antibodies to $\mathrm{Hl}$ of one or more isotypes were found in $74 \%$ of the 111 serum samples. Although AcHA were seen in $68 \%$ of serum samples, only $32 \%$ had AcHA of any isotype raised to greater than twice the normal level. Figure 1 illustrates the range of values of AcHA in the 111 serum samples.

Table 2 gives the prevalence of each isotype of AcHA and antibodies to H1. Most serum

Table 2 Antibodies to total core histones and histone $\mathrm{HI}$ in 111 patients with systemic lupus erythematosus

\begin{tabular}{lll}
\hline Isotype(s) & $\begin{array}{l}A c H A^{*} \\
(\%)\end{array}$ & $\begin{array}{l}H 1 \\
(\%)\end{array}$ \\
\hline IgG & $49(9)$ & $54(21)$ \\
IgM & $46(13)$ & $14(0)$ \\
IgA & $37(4)$ & $32(0)$ \\
IgG, IgM, or IgA & 68 & 55 \\
IgG, IgM, and IgA & 21 & 6
\end{tabular}

${ }^{*}$ AcHA=Antibodies to core histones. The figures in brackets represent the percentage of serum samples with that isotype alone. 
samples with AcHA or antibodies to $\mathrm{Hl}$ had more than one istoype. Additionally, all serum samples with IgG or IgA AcHA alone had only minimally raised levels. Similarly, 12 of the 15 serum samples with only IgM AcHA had low

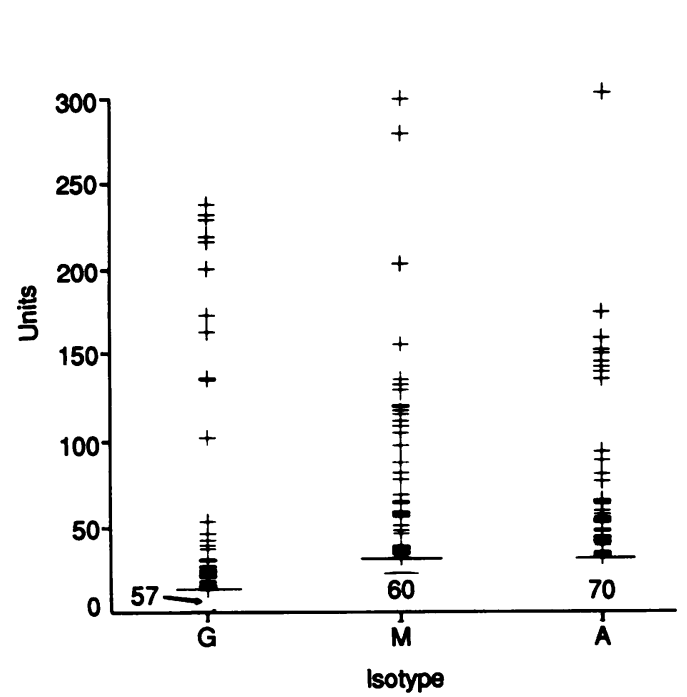

Figure 1 Levels of IgG, IgM, and IgA antibodies to core histones in serum samples from patients with systemic lupus erythematosus. Horizontal lines show the upper limit of normal. Figures below these lines represent the number of serum samples with normal levels of antibodies.
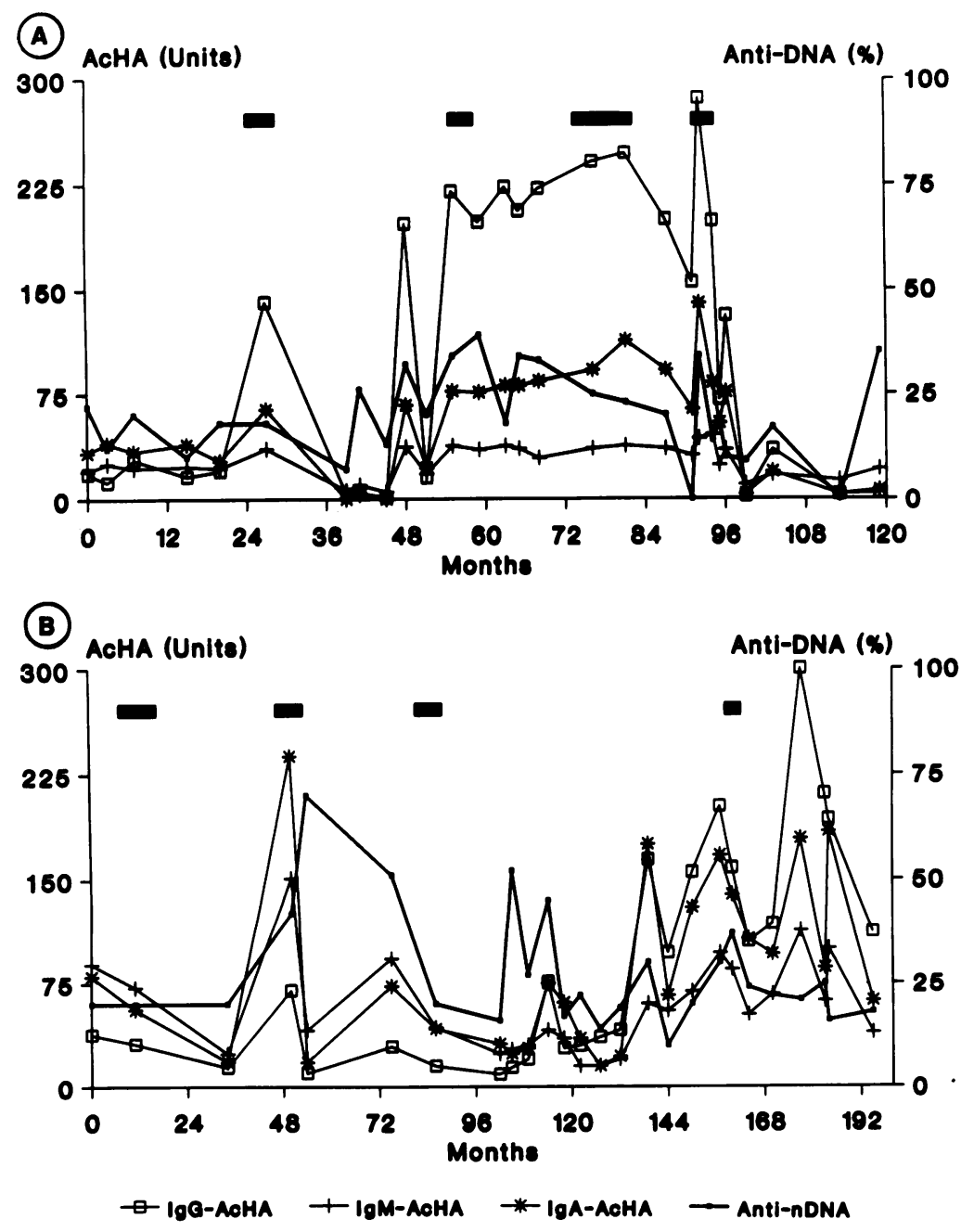

Figure 2 Changes in IgG, IgM, and IgA AcHA and antibodies to native DNA with time and their relationship to periods of active disease (represented by the solid bars at the top of the figure). (A) Patient with an association between AcHA and active disease; $(B)$ representative patient in whom no such association was shown. Units are as defined in the text.
Table 3 Antibodies to individual core histones and histone complexes in patients with systemic lupus erythematosus

\begin{tabular}{|c|c|c|c|}
\hline \multirow{2}{*}{$\begin{array}{l}\text { Histone } \\
\text { or } \\
\text { complex }\end{array}$} & \multicolumn{3}{|l|}{ Isotype } \\
\hline & $\begin{array}{l}I g G \\
(n=24)\end{array}$ & $\begin{array}{l}I g M \\
(n=20)\end{array}$ & $\begin{array}{l}\operatorname{Ig} A \\
(n=17)\end{array}$ \\
\hline $\begin{array}{l}\text { H2A } \\
\text { H2B } \\
\text { H2A-H2B } \\
\text { H3 } \\
\text { H4 } \\
\text { H3-H4 } \\
\text { None }\end{array}$ & $\begin{array}{r}19 \\
15 \\
2 \\
18 \\
1 \\
1 \\
1\end{array}$ & $\begin{array}{r}15 \\
13 \\
1 \\
10 \\
8 \\
2 \\
1\end{array}$ & $\begin{array}{r}11 \\
12 \\
2 \\
13 \\
2 \\
2 \\
1\end{array}$ \\
\hline
\end{tabular}

levels of antibody. The remaining three serum samples had moderately high levels.

Although IgG antibodies to $\mathrm{Hl}$ were present in all but one serum sample having any isotype of antibodies to $\mathrm{Hl}$, it was uncommon for a serum sample to have all three isotypes of antibodies to $\mathrm{Hl}$. In contrast, with IgG antibodies to $\mathrm{H} 1$, no serum sample had IgM or IgA antibodies to $\mathrm{Hl}$ alone. Strong correlations $(\mathbf{p}<0.001)$ were observed between the levels of each isotype of AcHA. Table 3 shows that antibodies to H2A, H2B, and $\mathrm{H} 3$ occurred in similar proportions, irrespective of the isotype; however, with the exception of $\operatorname{Ig} M$ antibodies, antibodies to $\mathrm{H} 4$ were detected infrequently. Only a small number of serum samples $(2 \%$ of the 111 samples) exhibited reactivity with histone complexes in the absence of antibodies to the component histones.

\section{ASSOCIATIONS OF ANTIBODIES TO HISTONES}

Table 4 shows that very few significant clinical or laboratory associations of AHA were noted. Although an association with psychiatric disturbance was documented, there was no overall association with central nervous system involvement. The associations with ulceration of the mouth and lymphopenia were detected when the three major isotypes were considered together, but no such associations existed with individual isotypes of AcHA. There were no associations with rheumatoid factor, C3, C4, or antibodies to extractable nuclear antigen. Only the association between IgG AcHA and raised levels of antibodies to native DNA had a $\mathrm{p}$ value less than 0.01 .

CHANGES IN ANTIBODIES TO HISTONE WITH TIME Of the 13 patients tested, only two had IgM AcHA with little or no IgG AcHA in the earliest serum samples tested. These two patients subsequently developed high levels of IgG AcHA (after 25 and 34 months), but high levels of IgM AcHA also persisted. Although antibodies to individual histones varied over time, in no patient was there a lasting change in the profile of antibodies (e.g. a switch from antibodies to $\mathrm{H} 2 \mathrm{~A}$ to antibodies to $\mathrm{H} 3$ ). Neither was there a profile of antibodies to the individual histones that was associated with active disease. Despite the paucity of IgG antibodies to $\mathrm{H} 4$ in the cross sectional study, each of the 13 patients studied over a long time period had IgG antibodies to $\mathrm{H} 4$ on one or more occasions. 
Table 4 Clinical and laboratory associations of antibodies to histones

\begin{tabular}{llll}
\hline Characteristic & Antibodies & Isotypes & $p$ Value $^{*}$ \\
\hline Mouth ulceration & AcHA† & All & 0.0188 \\
Psychiatric\$ & AcHA & IgA & 0.0416 \\
Antibodies to native DNA $(>20 \%)$ & AcHA & IgG & 0.0032 \\
& H1 & IgA & 0.0174 \\
Lymphopenia & AcHA & All & 0.0448 \\
\hline
\end{tabular}

*Pearson $\chi^{2}$ test.

tAntibodies to core histones.

†Raised IgG, IgM, or IgA antibodies.

Organic brain syndrome, psychosis, or severe affective disorder.

RELATIONSHIP BETWEEN AHA, ANTIBODIES TO NATIVE DNA, ERYTHROCYTE SEDIMENTATION RATE, AND DISEASE ACTIVITY IN THE

LONGITUDINAL STUDY

When all the patients were considered, the periods of disease activity were associated with higher levels of IgG AcHA $(p<0.05)$, IgA AcHA ( $<<0.05)$, and antibodies to native DNA $(\mathrm{p}<0.01)$, but not IgM AHA or erythrocyte sedimentation rate. However, there was no association between disease activity and any of these parameters when categorised as normal or abnormal. That is, raised levels of IgG and IgA AcHA as well as antibodies to native DNA were found when the SLE was inactive, but even higher levels were seen during the active phases. Similarly, no associations were noted with any isotype of antibody to $\mathrm{Hl}$.

When the patients were considered individually, only one showed a clear association between AcHA and disease activity with $\mathrm{p}<0.001$ for each of $\operatorname{IgG}, \operatorname{IgM}$, and $\operatorname{IgA}$ AcHA (fig 2). There was no association with antibodies to native DNA or erythrocyte sedimentation rate in this patient. One other patient had associations between antibodies to native DNA, erythrocyte sedimentation rate, and disease activity.

\section{Discussion}

The reported prevalence of AHA in unselected patients with SLE has varied from $21^{3}$ to $81 \% .^{4}$ We detected AHA in 74\% (AcHA in $68 \%$ and antibodies to $\mathrm{Hl}$ in $55 \%$ ) of patients, but only $32 \%$ of the serum samples with AcHA had greater than twice the normal levels. These results are remarkably similar to the findings of Muller et $a l,{ }^{30}$ who detected AHA in $78 \%$ of patients but noted that only $34 \%$ had high titres. Consequently, the ability to detect low levels of antibody may explain some of the wide variations in prevalence data. In addition, differences between patient groups, as illustrated in table 1, may go part of the way to explaining disparities in the prevalence and specificities of AHA cited in various reports.

Antibodies to core total histones of the three major isotypes were common and occurred with similar frequencies. Most patients had more than one isotype of AHA which, in longitudinal studies, could persist over many years.

Although it was not possible to study serum samples from patients before the onset of SLE, in no patient was there evidence that a switch from IgM to IgG AHA, with subsequent loss of IgM AHA, had occurred. IgA AHA have been described previously, but not detailed, in patients with SLE. ${ }^{31}$ From this study, it can be seen that IgA AHA occur at a similar frequency to the other isotypes of AHA.

Several studies have reported the prevalence of antibodies to individual core histones but there has been no general agreement as to the prevalence of each fraction. ${ }^{3} 561013-2030$ Of the core histones, most have found that antibodies to H2B are common and that antibodies to $\mathrm{H} 4$ are uncommon, whereas the reported prevalences of antibodies to $\mathrm{H} 2 \mathrm{~A}$ and $\mathrm{H} 3$ have varied greatly. Antibodies to $\mathrm{Hl}$ have been reported to be the most common of the antibodies to individual histones in most studies, but this has not been a universal finding. Although several reports have noted a predominance of antibodies to $\mathrm{H} 1$ and $\mathrm{H} 2 \mathrm{~B}$, most agree that a considerable diversity in the profiles of AHA may be seen in patients with SLE. Apart from a single study finding IgA antibodies to $\mathrm{H} 1$ in $18 \%$ of patients with SLE, ${ }^{32}$ IgA antibodies to individual histones have not been detailed. The data presented here suggest that antibodies to each of the histones, except H4, are common. Furthermore, for the core histones, all three major isotypes occur with similar frequencies, whereas IgM antibodies to $\mathrm{H} 1$ were less common than the other isotypes of antibodies to $\mathrm{Hl}$.

Antibodies to H2A-H2B complexes are characteristic of procainamide related lupus erythematosus $^{33}$ and have been noted in a minority of patients with idiopathic SLE. ${ }^{173}$ The data presented here confirm that this specificity is uncommon in patients with SLE (less than $2 \%$ of patients). Antibodies to $\mathrm{H} 3-\mathrm{H} 4$ complexes were detected in only two patients. This specificity has not been observed previously in patients with SLE, possibly because of its rarity. Nonetheless, a monoclonal antibody to this complex has been described ${ }^{34}$ and we have found that these antibodies occur in quinidine related lupus erythematosus ${ }^{25}$ and Felty's syndrome. ${ }^{26}$

Very few clinical or laboratory associations were evident, which is consistent with other studies. ${ }^{35}$ When compared with patients with other autoantibodies, Fritzler et al ${ }^{36}$ reported that patients with AHA had a lower incidence of several clinical and laboratory features of SLE. However, none of the AHA positive group of patients had raised levels of antibodies to native DNA and are thus likely to represent a subset of patients with milder SLE. The associations in our study with mouth ulceration, psychiatric disturbances, and lymphopenia were all weak and a prospective analysis will be needed to determine whether they are genuine. The association with antibodies to native DNA (seen here only with IgG AcHA) or antibodies to denatured DNA has also been observed by most, ${ }^{378} 37$ but not all, workers. ${ }^{6}$

The relationship between disease activity and the presence of AHA is unclear. Although several studies have shown an association, ${ }^{6-9}$ it is important to note that some studies failed to control for stronger associations between antibodies to native DNA and disease activity. In one of these studies, ${ }^{9}$ there was a negative association with antibodies to $\mathrm{Hl}$, despite the association between disease activity and anti- 
bodies to total histones. In contrast, other studies have failed to show an association between AHA and disease activity. ${ }^{10-12} 35$ Another study showed no association between activity and AHA overall, but commented that an association was seen in some patients. ${ }^{3}$ This study supported the possibility that increasing levels of AcHA may be a marker of disease activity when all patients are considered together. However, no such association could be found in most of the individual patients.

The tissue deposition of AHA may result in only low levels being present in the serum, thus obviating the identification of clinical associations. Histone aggregates have been shown to have an affinity for the basement membrane and are able to bind AHA. ${ }^{38}$ This is probably related to the highly cationic nature of histones, a property which may allow histone containing immune complexes to be nephritogenic. ${ }^{39-41}$ In vivo, the source of such histones could be in complexes with DNA in the form of oligonucleosomes which have been detected in serum samples from some patients with SLE. ${ }^{42}$ Importantly, preliminary data indicate that immune complexes involving histone-DNA complexes are also likely to be cationic. ${ }^{43}$ Despite these studies offering insights into the possible tissue deposition of AHA and subsequent pathology, caution is warranted in view of the fact that no study has shown an association between renal involvement and either high or low levels of AHA. Moreover, AHA are a prominent feature of drug induced lupus erythematosus in which renal involvement is very unusual. ${ }^{334445}$ It is reasonable to conjecture that only a subgroup of AHA are deposited, but this will remain hypothetical until AHA are eluted from the tissues and their specificities and properties studied.

In summary, we have shown that all major isotypes of AHA are common in patients with SLE. Whether all isotypes are considered together or separately, there were few clinical or laboratory associations. Moreover, our findings indicate that individual AHA levels are of no assistance in assessing disease activity, whereas sequential levels may be of limited value in a minority of patients.

MGC was the recipient of the FG Spurway Fellowship from the Arthritis Foundation of Australia. This work was supported in part by the Sutton Rheumatism Research Funds and National pealth and Medical Research Council of Australia grant number 850657. The authors thank Miss Tammy Lye for her expert secretarial assistance.

1 Burlingame R W, Love W E, Wang B-C, Hamlin R, Xuong N-H, Moudrianakis E N. Crystallographic structure of octameric histone core of the nucleosome at a resolution of 3.3 A. Science 1985; 228: 546-53.

2 Wu R S, Panusz H T, Hatch C L, Bonner W M. Histones and their modifications. CRC Crit Rev Biochem 1986; 20: $201-63$.

3 Krippner H, Springer B, Merle S, Pirlet K. Antibodies to histones of the IgG and IgM class in systemic lupus erythematosus. Clin Exp Immunol 1984; 58: 49-56.

4 Boey M L, Peebles C L, Tsay G, Feng P H, Tan E M. Clinical and autoantibody correlations in Orientals with systemic lupus erythematosus. Ann Rheum Dis 1988; 47: 918-23.

5 Rubin R L. Antihistone antibodies. In: Lahita R G, ed. Systemic lupus erythematosus, New York: Wiley, 1987: 271-89.

6 Konstantinov K, Russanova V, Russeva V. Antibodies to histones and disease activity in systemic lupus erythematosus: a comparative study with an enzyme-linked immunosorbent assay and immunoblotting. Arch Dermatol immunosorbent assay and
7 Gioud M, Ait Kaci A, Monier J C. Histone antibodies in systemic lupus erythematosus. A possible diagnostic tool. Arthritis Rheum 1982; 25: 407-13.

8 Meyer O, Cyna L, Haim T, Ryckewaert A. Les anticorps anti-histones de type IgG. Valeur diagnostique au cours de la polyarthrite rhumatoide, de la sclerodermie, de la maladie lupique spontanee et medicamenteuse. Rev maladie lupique spontanee

9 Helve T, Gripenberg M, Kurki P, Teppo A-M, Wegelius O. Enzyme-linked immunosorbent assays for antibodies to poly (A), poly dAT and histones: possibly useful tools for the evaluation of prognosis and disease activity in systemic lupus erythematosus. Rheumatol Int 1984; 4: 75-8.

10 Bernstein R M, Hobbs R N, Lea D J, Ward D J, Hughes G R V. Patterns of antihistone antibody specificity in systemic rheumatic disease. I. Systemic lupus erythematosus, mixed connective tissue disease, primary sicca syndrome, rheumatoid arthritis with vasculitis. Arthritis Rheum 1985; 28: 285-93.

11 Epstein A, Greenberg M, Halbert S, Kramer L, Barland P. The clinical application of an ELISA technique for the detection of antihistone antibodies. $\mathcal{F}$ Rheumatol 1986; 13: detection.

12 Fishbein E, Alarcon-Segovia D, Vega J M. Antibodies to histones in systemic lupus erythematosus. Clin Exp Immunol 1979; 36: 145-50.

13 Bustin M, Reisch J, Einck L, Klippel J H. Autoantibodies to nucleosomal proteins: antibodies to HMG-17 in autoimmune diseases. Science 1982; 215: 1245-7.

14 Costa O, Monier J-C. Antihistone antibodies detected by ELISA and immunoblotting in systemic lupus erythematosus and rheumatoid arthritis. $\mathcal{F}$ Rheumatol 1986; 13: 722-5.

15 Craft J E, Radding J A, Harding $M$ W, Bernstein R M, Hardin J A. Autoantigenic histone epitopes: a comparison between procainamide- and hydralazine-induced lupus. Arthritis Rheum 1987; 30: 689-94.

16 Gohill J, Cary P D, Couppez M, Fritzler M J. Antibodies from patients with drug-induced and idiopathic lupus erythematosus react with epitopes restricted to the amino and carboxyl termini of histones. $\mathcal{F}$ Immunol 1985; 135: 3116-21.

17 Portanova J P, Arndt R E, Tan E M, Kotzin B L. Antihistone antibodies in idiopathic and drug-induced lupus recognize distinct intrahistone regions. $\mathcal{f}$ Immunol 1987; 138: 446-51.

18 Rubin $R$ L, Waga S. Antihistone antibodies in systemic lupus erythematosus. $\mathcal{F}$ Rheumatol $1987 ; 14$ (suppl 13): 118-26.

19 Shoenfeld Y, Segol G, Segol O, et al. Detection of antibodies to total histones and their subfractions in systemic lupus erythematosus patients and their asymptomatic relatives. Arthritis Rheum 1987; 30: 169-75.

20 Thomas J O, Wilson C M, Hardin J A. The major core histone antigenic determinants in systemic lupus erythematosus are in the trypsin-sensitive regions. FEBS Let 1984; 169: 90-6.

21 Tan E M, Cohen A S, Fries J F, et al. The 1982 revised criteria for the classification of systemic lupus erythematosus. Arthritis Rheum 1982; 25: 1271-7.

22 Urowitz M B, Gladman D D, Tozman E C S, Goldsmith C H. The lupus activity criteria count (LACC). $\mathcal{F}$ Rheumatol 1984; 11: 783-7.

23 Wells J V, Webb J, Van Deventer M, et al. In vivo antinuclear antibodies in epithelial biopsies in SLE and other connective tissue diseases. Clin Exp Immunol 1979; 38: 424-35.

24 Webb J, Whaley $\mathrm{K}$. Evaluation of the native DNA-binding assay for DNA antibodies in systemic lupus erythematosus and other connective tissue diseases. Med F Aust 1974; 2 324-8.

25 Cohen M G, Kevat S, Prowse M, Ahern M. Two distinct quinidine-induced rheumatic syndromes. Ann Intern Med 1988; 108: 369-71.

26 Cohen M G, Webb J. Antihistone antibodies in rheumatoid arthritis and Felty's syndrome. Arthritis Rheum 1989; 32: 1319-24.

27 Bohm E L, Strickland W N, Strickland M, Thwaits B H, Van Der Westhuizen D R, Von Holt C. Purification of the five main calf thymus histone fractions by gel exclusion chromatography. FEBS Lett 1973; 34: 217-21.

28 Rubin R L, McNally E M, Nusinow S R, Robinson C A, Tan E M. IgG antibodies to the histone complex H2A-H2B characterize procainamide-induced lupus. Clin Immunol Immunopathol 1985; 36: 49-59.

29 Yokohari R, Tsunematsu T. Application, to Japanese patients, of the 1982 American Rheumatism Association revised criteria for the classification of systemic lupus erythematosus. Arthritis Rheum 1985; 28: 693-8.

30 Muller S, Bonnier D, Thiry M, Van Regenmortel M H V. Reactivity of autoantibodies in systemic lupus erythematosus with synthetic core histone peptides. Int Arch Allergy Appl Immunol 1989; 89: 288-96.

31 Rubin R L, Joslin F G, Tan E M. Specificity of anti-histone antibodies in systemic lupus erythematosus. Arthritis Rheum 1982; 25: 779-82.

32 Costa O, Tchouatcha-Tchouassom J C, Roux B, Monier J C. Anti-H1 histone antibodies in systemic lupus erythematosus: epitope localisation after immunoblotting of chymotrypsin digested H1. Clin Exp Immunol 1986; 63: 608-13.

33 Totoritis M C, Tan E M, McNally E M, Rubin R L. Association of antibody to histone complex H2A-H2B with symptomatic procainamide-induced lupus. $N$ Engl $\mathcal{f}$ Med 1988; 318: $1431-6$.

34 Laskov R, Muller S, Hochberg M, Giloh H, Van Regenmortel 
M H V, Eilat D. Monoclonal autoantibodies to histones from autoimmune NZB/NZW $\mathrm{F}_{1}$ mice. Eur $\mathcal{f}$ Immunol 1984; 14: 74-81.

35 Gompertz N R, Isenberg D A, Turner B M. Correlation between clinical features of systemic lupus erythematosus and levels of antihistone antibodies of the IgG, IgA and IgM isotypes. Ann Rheum Dis 1990; 49: 524-7.

36 Fritzler M, Ryan P, Kinsella T D. Clinical features of systemic lupus erythematosus patients with antihistone systemic lupus erythematosus patients

37 Gripenberg M, Helve T, Kurki P. Profiles of antibodies to histones, DNA and IgG in patients with systemic rheumatic diseases determined by ELISA. $\mathcal{F}$ Rheumatol 1985 12: 934-9.

38 Schmiedeke T M J, Stockl F W, Weber R, Sugisaki Y, Batsford S R, Vogt A. Histones have high affinity for the glomerular basement membrane. Relevance for immune complex formation in lupus nephritis. $\mathcal{J}$ Exp Med 1989; 169: $1879-94$.

39 Gallo G R, Caulin-Glaser T, Lamm M E. Charge of circulating immune complexes as a factor in glomerula basement membrane localization in mice. $\mathcal{f}$ Clin Invest 1981; 67: 1305-13.
40 Adler S G, Wang H, Ward H J, Cohen A H, Border W A. Electrical charge. Its role in the pathogenesis and prevention of experimental membranous nephropathy in the rabbit. $\mathcal{F}$ Clin Invest 1983; 71: 487-99.

41 Vogt A, Rohrbach R, Shimuzu F, Takamiya H, Batsford S. Interaction of cationized antigen with rat glomerular basement membrane: in situ immune complex formation. basement membrane: in situ
Kidney Int 1982; 22: 27-35.

42 Rumore $P$ M, Steinman C R. Endogenous circulating DNA in systemic lupus erythematosus. Occurrence as multimeric complexes bound to histone. $\mathcal{J}$ Clin Invest 1990; 86: 69-74.

43 Cohen M G, Gaston-Parry O. Isoelectricfocusing of antihistone antibodies in SLE, drug-related lupus erythematosus and Felty's syndrome. Br $\mathcal{F}$ Rheumatol 1981; 28 (suppl 1): 39 (abstract).

44 Harmon C E, Portanova J P. Drug-induced lupus erythematosus: clinical and serological studies. Clin Rheum Dis 1982; 8: 121-35.

45 Portanova J P, Rubin R L, Joslin F G, Agnello V D, Tan E M. Reactivity of antihistone antibodies induced by procainamide and hydralazine. Clin Immunol Immunopathol 1982; 25: 67-79.

D

